\title{
Collective brand strategy, entrepreneurship, and regional growth: The role of a protected designation of origin (PDO)
}

\author{
Erik A. Borg, Karl Gratzer \\ Sodertorn University, Alfred Nobels Alle 9, 14189 Huddinge, Sweden \\ Email address: \\ erik.borg@sh.se(E. A. Borg), karl.gratzer@sh.se(K. Gratzer)
}

To cite this article:

Erik A. Borg, Karl Gratzer. Collective Brand Strategy, Entrepreneurship, and Regional Growth: The Role of a Protected Designation of Origin (PDO). Journal of World Economic Research, Vol. 2, No. 3, 2013, pp. 26-38. doi: 10.11648/j.jwer.20130203.11

\begin{abstract}
This research aims to interconnect entrepreneurship theories with brand theories. The study analyzes how this can be accomplished in the context of smaller agricultural firms, considering how intellectual property rights can be used strategically in entrepreneurial activities, ultimately creating regional growth. A firm has several options to protect its brands. Producers of similar products within a limited geographical area can protect the shared designated origin. Use of a collective brand, such as Champagne and Roquefort in France or Parmeggiano Reggiano in Italy, has been studied as a strategy to protect products from a given region. In the case analyzed here, a particular Austrian collective brand - Gailtaler Almkäse - was safeguarded within a protected designation of origin (PDO), providing producers a safe haven from which to enhance their collective brand in competitive markets. The PDO registration of the brand represents a central entrepreneurial strategy for manufacturers. To the region where the brands originate, the PDO has become a specific aspect of entrepreneurship that leads regional development.
\end{abstract}

Keywords: Brand, Entrepreneurship, Regional Growth, Strategy

\section{Introduction}

The role of brands in entrepreneurial theory is underresearched. Access to a well established and recognized brand can be crucial to entrepreneurial prosperity. The Schumpeterian school of entrepreneurship theory can be contrasted to what can be described as a 'business school approach' to entrepreneurship. Furthermore, theories of entrepreneurship and of brand strategy can be linked, and entrepreneurship has previously been associated with firm strategy (Dess et al. 1999; Ireland et al. 2009; Knight 2000; Morris and Paul 1987; Wright and Dana 2003). Similarly, prior research has connected theories of brands and of strategy (De Chernatony 1997; Keller et al. 2008 and van Gelder 2004). Strategy is located at the intersection of brands and entrepreneurship, and can be explored when formulating brand theories of entrepreneurship relevant to the collective brands associated with a protected designation of origin (PDO). Brand strategy development can be understood in light of attempts to pursue new entrepreneurial ventures with a strong regional basis.
Empirically, a brand can be integral to the development of an entrepreneurship strategy in which several brands are protected collectively. A group of brands in a specific geographical region can be protected by a protected designation of origin (PDO). A PDO represents a brand strategy in which the country or region of origin is the significant characteristic that distinguishes the brands in the region. The region of origin becomes a source of a collective brand strategy that can enhance the entrepreneurship of the region. The empirical part of this research examines the Austrian alpine region of Gailtal and its production of Almkäse cheese. Methodologically, the research is based on an analytical synthesis of theoretical approaches related to relevant aspects of entrepreneurship, brands, and strategy. The empirical evidence comes from a regional case study and is derived from secondary sources and interviews.

\section{PDOs and Regional Growth}

Although nations have been the usual unit of analysis in studies of economic growth, economic performance obviously differs substantially between regions within 
nations (Porter 2003). This was obvious in the late 1980s and 1990s when some regions grew much faster than the slow-growth regions. A PDO certification relates to local knowledge and innovation that has evolved over a long period. By defining this knowledge and protecting it from competitors outside the specific region of origin, the certification can spur regional growth by ensuring increased return on investment. The brand recognition means that the certified products can command higher prices. The certification process leads to regional division of labour through specialization under collective brands. Such regional growth is empirically associated with two processes: first, the transfer and creation of knowledge and innovation, which have a regional dimension because of their localized nature; second, the differentiation of growth between regions, which can be related to monopsonistic competition and increased return to scale (Werker and Athreye 2004).

Regional development in the agricultural sector, which is particularly relevant to PDOs, has previously been studied from several perspectives, including the relationship between PDOs and rural development (Vakoufaris 2010), and the role of collective action by agri-food SMEs in developing rural areas (Lamprinopoulou 2006). The abilities of rural agri-food businesses to internationalize (Bertolini and Giovannetti 2006) and of local entrepreneurs to use local natural resources have also been researched (Nikolaou et al. 2011). However, the relationship between rural development and the protection and development of local skills and resources merits further attention. It is evident that local agribusiness entrepreneurship that is protected by a PDO can be developed through a collective brand strategy. The protection of local skills can be embedded in the geographical indication (GI) scheme instituted by the European Union.

A PDO certification can be a source of entrepreneurship and regional growth. A PDO differs from a protected geographical indication (PGI), which provides less strict protection of a geographical indication (GI). For practical and analytical purposes, we are concentrating our analysis on PDOs, which offer the most comprehensive protection of GIs. The European Union started protecting geographical indications in 1992, to contribute to sustainable rural development (Vakoufaris 2010). The EU considered that PDOs and PGIs had an important role to play in the regeneration of the countryside since they ensure that agri-foodstuffs are produced in a way that preserves local plant varieties, rewards local people, supports rural diversity and social cohesion' (Commission of the European Communities 2008, p. 12).

Regional economic policy initiatives often focus on encouraging new business start-ups, providing business support, and supporting regionally important clusters (Huggins and Williams 2011). As an economic policy, the recognition of a PDO serves to encourage the development of existing agribusinesses and the start-up of new ones.
Once this certification is recognized, it enables new firms to enter into a specific business. The collective brand enhances new companies' competitive advantage in markets outside the specified region.

The PDO specifies an innovation for which the production process, from raw materials to finished product, occurs primarily within the designated region. The main aspects of quality, such as colour, flavour, or smell, should be linked to local knowledge, climate, and soil quality. Furthermore, the products should have been produced in the same way at the same location for more than 25 years. A PDO normally applies to a group of manufacturers, and can only be awarded to a single producer if this manufacturer is the sole producer in a region (Gratzer and Rytkönen 2012).

A region with specific knowledge and innovation can be a source of dynamism (Malecki 1997). Innovative firms and knowledgeable individuals can relate to each other when they operate in the same vicinity. Companies readily form interactive networks that help them use their human and financial capital. Networks have previously been studied from various perspectives and within various research traditions (Borg 1991, 2001; Casson 2010; Granovetter 1973; Hakansson and Johanson 1994; Huggins and Johnston 2010; Johannisson and Rezpasillas 2002). Regions with established networks, embedded in relationships generated by PDOs, represent entrepreneurial opportunities for companies. Through agri-food networks, regional companies can take collective action to achieve common goals (Lamprinopoulo et al. 2006). External circumstances can explain how entrepreneurship develops (Korsgaard 2011). A region can foster the positive effects of concentration through what is called agglomeration. The regional proximity of producers of similar products fosters a dynamism that can lead to regional growth. At the same time, the opposite process, deglomeration, can occur. Innovators and competitors may get in each others' ways and congestion can lead to slower growth. Regional entrepreneurship represents a combination of factors, in which the interplay between regional companies strengthens or, in some cases, weakens the involved actors. Central to the outcome of regional networking within PDOs is the strategy adopted to protect geographical indications that represent brands in the same region.

From the perspective of brands competing under the same regional banner, weaker brands may have great opportunities to borrow some of the goodwill of the strong brands in the same region protected by the PDO. The new protection attracts new competitors to the region and increases the competitive pressure on existing firms. The strongest brands in the protected French Champagne region can manage well without the regional protection because of their own strong brand recognition. For weaker brands, being able to refer to the strong regional protection provides effective competitive advantage, i.e. the competitive advantage lies in the co-branding with stronger brands. The existence of well established and recognized 
regional brands paved the way for a PDO. As a brand strategy, it makes sense for the brands to choose collective branding if the collective brand recognition is stronger than that of the sum of the individual brands. Adopting a new brand can be a source of market orientation (Jaworski and Kohli 1993). The early adopters of the PDO will have a first-mover advantage, being the first to fall under the new regional recognition. The late adopters will be able to consider the effects of collective brand recognition before adopting the certification in their own marketing strategies.

\section{Two Alternative Approaches to Studying Entrepreneurship}

The literature presents brands as an increasingly important economic resource in the global market because they are considered a strategic resource for firms. Brands can be assigned enormous values in company evaluations (Aaker 1991; De Chernatony et al. 2000). Today, we distinguish between a brand as a characteristic of a product or group of products, i.e. a brand, or of a firm, i.e. a collective brand such as IKEA or Nike. Despite the fact that it is assumed that innovative firms strive to create strong collective brands, this has not previously been studied from an entrepreneurial perspective. Attempts to connect brands to entrepreneurship theories are of great importance inside and outside the scientific arena.

The view that entrepreneurship has become an increasingly important tool for achieving various economic policy goals is now widespread. Research into entrepreneurship is extensive, and has given rise to various influential concepts and theories that have gained wide acceptance. This multiplicity of schools of thought can be divided into two main streams, called the business school approach and the Schumpeterian school.

The business school approach (Birch 1979; Davidsson 1990; Delmar 1996; Gartner 1988; Shane 2003) is probably the best established approach in academic entrepreneurship research and it is the most established approach among designers of economic policy. In this perspective, entrepreneurship is operationalized mainly by measuring the number of new firms. The underlying ideology is individualistic, and this perspective often characterizes the entrepreneur as a true pioneer, a hero swimming against the tide who gets the better of established routines. The entrepreneur concept is normally used synonymously with small entrepreneurs, however, which results in a lack of validity. Other disadvantages are that, through this operationalization, this perspective does not capture innovative change in new or existing organizations and that the connection to theory is weak or nonexistent. The advantage of the approach is that it uses data that are easily available internationally, which facilitates comparisons.

The Schumpeterian school (Casson 2006, 2010; Landström and Lohrke 2010; Parker 2006; Polenske 2007) emphasizes innovation. According to Schumpeter (1911), the concept of innovation covers a wide range of matters, including introducing new goods, technical change in the production of existing goods, opening new markets or sources of raw material, and creating new types of business organizations - i.e. anything that can be characterized as 'doing things differently' in economic life - that create and change the world and drive development forward. The person who implements the innovation and only that person is defined by Schumpeter as an entrepreneur.

The distinction between those who implement something new and those who imitate something existing constitutes the basis of Schumpeterian theory of economic development. The disadvantages of this approach are that valid data on innovation are often difficult to find and operationalizing the macro-analytical concepts of the model might be problematic. Entrepreneurship exists as a component of the Schumpeterian innovation process but takes only a minor role. Ideally, entrepreneurs start new firms around their new business ideas but, according to Schumpeter, innovations also frequently occur in existing firms. The advantages of the model are that its measurement indicators are well connected to theory and that it provides analytical tools for distinguishing between economic, quantitative growth and qualitative development.

Few users of Schumpeterian theory seem to know that by the late 1930s there were already clear signs that Schumpeter himself was dissatisfied with the entrepreneurial theory that he had formulated in 1911. Dissatisfaction with the original theory became clear in Schumpeter's Business Cycles (1939) and in the economic sections of Capitalism, Socialism and Democracy (1942), in which Schumpter emphasized the entrepreneurial function rather than the individual entrepreneur per se. He argued that the individual who often discharged the entrepreneurial function in early capitalism was declining in importance at an increasing speed. Schumpeter claimed that innovation in a world increasingly characterized by large firms was becoming institutionalized and routinized. The entrepreneurial function can consequently also be discharged by firms, networks, government authorities, and institutions and through cooperation with public organizations and industry. An innovation no longer needs to be 'of the first degree'; instead, it might concern less fundamental changes, such as the introduction of new brands or new ways of organizing the distribution of goods.

In earlier research into entrepreneurs and brands, large industrial firms have often been the objects of study. Entrepreneurship, innovation, and brands have therefore often been described from an industrial product perspective. Many people have connected innovation with the implementation of technical innovations that are important from a historical perspective, such as the steam engine, electric motor, or laser beam. The creation of intellectual property has more recently been considered a way of innovating. Intellectual property includes patents, copyrights, organizational solutions, patent protection, and 
brands. These property rights might be important tools for entrepreneurial activities.

\section{Branding as a Regional Strategic Tool}

Creating added value has been viewed as essential to economic performance (De Chernatony et al. 2000). Market value has in turn been associated with brands (Keller et al. 2008). A region can adopt a brand strategy to increase the value of its products. A successful brand strategy can give the producer global brand leadership (Aaker and Joachimstaler 2000; Van Gelder 2004). The value of a brand can best be described in terms of brand equity, which can be interpreted in at least three ways (Feldwick 1996). First, brand equity can be regarded as a separate asset and appear in the balance sheet, in what is also called brand value. Second, it can be viewed as the strength of customer attachment to a brand, which is also called brand strength or brand loyalty. Third, brand equity can capture the subjective associations and beliefs customers have about the brand, which is called brand image (Wood 2000). All three of these definitions are relevant to a collective regional brand. Each company included in the brand can view the collective brand as a separate asset. The brand emanating from a PDO augments the value of each brand included in the designated origin. Products from a region known for the quality of specific products are viewed as more valuable to consumers, who can then express loyalty to strong brands. A region such as Champagne in France has a strong image among consumers, who are willing to pay a premium for specific wine products from this region.

The value creation of a brand starts with marketing activities, and the financial value of the brand is derived from customers' relationships with it (Keller and Lehmann 2003). A region can choose to promote a specific product, marketing its producers by applying for a PDO. Just as a single product can be marketed, a region can use marketing tools to promote a range of products of common origin. Developing regional logos and brand recognition can represent a strategy for collective marketing communication. A strong brand tells a story about the product (Aaker 1996), and the history of a region and its traditional production represents such a story. The collective effort to preserve and protect a regional tradition is ideal for creating a strong brand story. As a regional development tool, the marketing of collective brands represents a unique opportunity for regions.

\section{Coordinating a Collective Brand Portfolio}

In a collective brand portfolio, several brands are commonly managed by a single corporation. Each brand has a different brand recognition and value in a competitive market. Typically, a small number of brands account for much of the brand value of the multiple brands managed in one brand portfolio. Brand portfolio management addresses the central issue of whether to add, retain, or delete an individual brand from a number of related brands (Varadarajan et al. 2006). Developing a brand strategy for a PDO involves coordinating a brand portfolio comprising several brands. The brand image of the PDO is similar to that of a corporate image, in that the brand image of a PDO's better-known brands extends to the lesser known brands. New brands established within the PDO will have to find a niche among the more established brands. When well coordinated, the various brands in a PDO can strengthen each other, representing various offerings covering a range of prices, quality levels, luxury values, and other attributes. Badly managed and coordinated, the various brands can cannibalize each other and lessen the positive collective effect of the coordinated PDO.

The brands in a PDO form a network of relationships with each other and with their customers, which can be represented in a relationship spectrum. The main brand, or master brand, is extended to the sub-brands through an endorser (Aaker 2004). The endorser is in this case the specific PDO regime that lends its reputation to the individual participating brands. Establishing ways of accepting, rejecting, or deleting brands from the PDO can be an effective means of managing a PDO's brand portfolio. As the PDO effectively endorses all the brands accepted by the collective brand, developing acceptance criteria is essential to the collective brand strategy. The PDO can be defined in terms of the intellectual property rights it represents, and that new brands falling under the same PDO will have to honour. The more specific the categories and criteria that the PDO defines, the more tools are established for the inclusion and exclusion of prospective brands.

A brand strategy presents choices to the brand developer. Corporations are known for establishing vastly different strategies for managing brands. A bundle of identities is merged in a collective brand strategy (Laforet and Saunders 1999). A major choice in developing a brand strategy is the level of emphasis on the corporate versus product image. Translated into the reality of a PDO, the brand can emphasize the image of either the region or the individual product. The best-known products of a PDO may have a product recognition that goes beyond the recognition of the region, and may benefit from emphasizing the product name and not the regional name. At the same time, a more recently established brand can benefit from the bandwagon effect caused by the regional PDO. A risk in associating too many brands with a collective brand through brand extension is that the brand may become diluted, making individual brands less attractive and calling into question the overall brand reliability (DelVecchio 2000). 


\section{Collective Brands and PDOs}

In markets with monopolistic competition, competing firms might create their own niches by differentiating their largely homogenous products. Creating an attractive collective brand is a tool for achieving this. By building an attractive collective brand, the seller can obtain a higher income and lower costs. A strong collective brand can be a powerful tool with which a firm can earn higher profits, enter new markets, and create monopoly-like conditions in existing markets. Identification through a brand is considered an emotional and cognitive process that helps customers reduce their search time and, accordingly, the search cost of finding the right goods. A strong brand often fetches a higher price, the higher price playing the role of a quality signal for the customer. We can observe that producers and consumers have different intentions and needs concerning brands, but that they are connected at a general level by two dynamic, growth-promoting and welfare-creating factors: higher returns and lower transaction costs.

Brands give ownership rights to words and symbols considered unique to a firm. A difference between a PDO and a brand is that a PDO product is linked to a specific territory in which production must take place. The area of production is always exactly defined; all stages of production can take place only in it and an objective relationship must exist between product quality and place of origin. A brand can be sold and its production relocated, which is not possible with a PDO product. The brand constitutes individual property, while a PDO is the collective property of all producers within the defined territory that produces the specified goods according to specified rules.

How can the original marks of origin be used to strengthen a collective brand? While a brand stipulates that a good originates within an individual firm, a geographical mark of origin distinguishes goods according to their geographical origins. Using an original mark of origin, goods are singled out according to their established national, regional, or local origins as opposed to others with different geographical origins. A PDO also indirectly serves as a tool for product differentiation and quality guarantee. Previous studies have demonstrated that PDO production may have the potential to contribute to rural development, since PDO products can fetch higher prices and earn higher profits. PDO production also gives the producing region a comparative competitive advantage by tying production to it. Production so defined cannot be relocated, so associated employment opportunities will remain and new ones can be created in the involved rural area.

In particular, the PDO strategy allows smaller producers in a given region to band together to register the intellectual property embodied in their products. These linked producers might feel that the registered products will shape their marketing, putting producers in a stronger position to defend their rights against infringement. The present study describes the case of Gailtaler Almkäse, in which producers acquired PDO certification that helped them enhance their collective brand. This turned out to be economically successful, not only for the firms but also for their region.

\section{The Gailtaler Almkäse Case}

Austria became an EU member on 1 January 1995. Even before membership had been formalized, Austrian authorities took measures to reinforce the competitiveness of rural firms. Two of the tools used were PDO and PGI certification of a number of food products. This case study examines how a cooperative of 13 cheese-producing mountain pasture areas succeeded in creating a strong collective brand by having their products PDO certified. This increased the profitability of the firms and reinforced their ability to survive, subsequently contributing to regional growth. The organization of food-related festivals interconnected tourism, gastronomy, and trade, creating important regional value added. The currently regionally and nationally well-known product from this mountain pasture cooperative is marketed under the trade mark 'Gailtaler Almkäse'. The product name refers to the sparsely populated valley of Gailtal in the federal state of Kärnten in southern Austria.

The study period extends from the establishment of this PDO project in 1995 - the year of Austrian entry into the EU - to 2010. We cite a few examples of festivals celebrating locally produced food products, held to increase the regional value added of locally produced food products. We chose to study this project because it illustrates how to design a strategy to counter the negative effects of globalization on rural development. Depopulation, closure of firms, and a decrease in the competitiveness of the countryside relative to cities have all recently attracted increased attention.

The Gailtaler Almkäse project is considered by local agents to have prevented the closure of agricultural firms and workplaces and to have succeeded in creating new activities in tourism, gastronomy, and trade. Though the total yearly production of cheese is relatively modest at about 60,000 tons, the value added by the cheese production is considerable for the small network of 13 producing family firms since it prevents farm closure. For the region as a whole, the economic importance of cheese production is relatively low. What is of economic importance for the region is the value added created by closely related food activities and their positive impact on tourism, restaurants, and handicrafts. The study also describes how, by organizing culinary festivals, the region has connected the production of locally produced food products to tourism, gastronomy, trade, and handicrafts. Accordingly, a regional value added has been generated that, according to many evaluators, greatly exceeds the value generated by the cheese production itself. 
The marketing activities were initiated and dealt with as was the earlier PDO application - by a network of national government and regional authorities and organizations. This network is among the reasons why the project is often cited as an example of best practice at the national and international levels. A main reason why we chose Gailtaler Almkäse as the case for our study is that Kärnten was awarded the best practice prize in the EU project Interreg III Alpine Space RegioMarket, 2006-2008. The aim of Interreg was to improve regional economies by developing trademark and marketing strategies for locally produced agrarian goods and to benefit small firms. Eighteen regions involved in seven EU projects participated in the project. Of interest in this context is that it was the federal state of Kärnten that proactively assumed an entrepreneurial role. Even before the start of Interreg, the agricultural department of the federal government of Kärnten established an administrative unit to prepare for participation in Interreg ( Lebensmittel Kaemten 2010; Regiomarket 2010).

\subsection{Gailtal: The Geographic, Economic, and Demographic Situation}

Gailtal's 13 involved mountain pasture areas are located in the political administrative district of Hermagor, consisting of seven municipalities, one of which is the small town of Hermagor located in the Oberkärnten region. The most important areas of interconnected habitation are situated in the valley of the River Gail and its tributaries, the Loisach and Gitschtal rivers. In the north, Gailtal's border is marked by the Gailtaler Alpen, and in the south, the Karnische Alpen constitutes a natural geographical border with Italy.

The population of this barren, alpine area is far below the average for the federal states of both Kärnten and Austria. The capital of the region, Hermagor, and the small market town of Kötschach-Mauthen are the two leading centres of employment in the area, which is dominated by tourism, particularly in the skiing region of Nassfeld. In total, $75 \%$ of all employed individuals and $55 \%$ of all inhabitants live in these two municipalities. Another disadvantage of the region is that its peripheral labour market is not connected to the supra-regional and national traffic system.

Table 1. Inhabitants and unemployment in Hermagor, Kärnten and Austria. 2008.

\begin{tabular}{lccc}
\hline & Hermagor & Kärnten & Austria \\
\hline Inhabitants & 19294 & 561094 & 8331930 \\
Share of women & 9877 & 289363 & 4277716 \\
Change between & -2.3 & 0.0 & 3.3 \\
2002 and 2008 & 5.5 & 7.2 & 5.8 \\
Unemployment & 6.5 & 7.0 & 5.6 \\
Men & 4.8 & 7.4 & 6.1 \\
Women & 24 & 59 & 99 \\
Inhabitants per & $\mathrm{km}^{2}$ & & \\
\hline
\end{tabular}

Table 1 indicates that Hermagor had 19,294 inhabitants ( $51.2 \%$ of whom were women) in 2008 , which corresponds to about $3.4 \%$ of the total population of Kärnten. In 2008 the population fell by $0.1 \%$ relative to 2007 , with a somewhat worse trend for women, i.e. a decline of $0.3 \%$. Hermagor was also the region with the worst population trend in Austria between 1991 and 2001, when the population decreased by $2.4 \%$. Given a slight excess of births over deaths in the region, this decline was entirely due to emigration. This negative trend also continued between 2002 and 2008, with a 2.3\% decrease in the population (Die Woche 2010); the corresponding figures for Kärnten were $0.0 \%$ and for Austria as a whole 3.3\%. The share of inhabitants with foreign citizenship was also low at $5.3 \%$, i.e. far below the Austrian average of $10.3 \%$, which is considered problematic (Von Schwarzfurtner 2009).

Because cheese production in the area had long been distinctive, a producers' association had been created in 1949 (Gemeinschaft der Almkäsereien Kärntens). In connection with the application for an EU PDO certificate in 1996, this association changed its name to one considered more obviously connected to the regional origins of the product (i.e. Verein der Gemeinschaft der Gailtaler Almsennereien). A protocol continuing the tradition of the medieval Alpordnung regulations determining, for example, what farms had the right to bring animals to mountain pastures, was established by the group active in creating the Gailtaler Almkäse project. The new protocol, Gailtaler Almprotokoll, came to play a key binding role in the future workings of the cooperative. The protocol was drawn up by 76 people, including nine women, active in the mountain grazing trade and constitutes binding guidelines for all members. Its 20 pages contain detailed regulations for the production and quality control of cheese covered by the PDO brand. It also provides binding instructions for animal care and for organizing operations in the mountain pastures. The most important aspect of the protocol might be the binding regulations for pricing (Gailtaler Almprotokoll 1994), stipulating a minimum price per $\mathrm{kg}$ of cheese for cartel members and directing members to monitor prices and adjust them annually (Gailtaler Almprotokoll 1994, p. 16). Finally, regional entrepreneurs should be used when implementing investment in the mountain pasture infrastructure (Gailtaler Almprotokoll 1994, p. 17).

Table 2 indicates a decrease in the total number of mountain pastures in Kärnten by 373 between 1891 and 2008, from 2334 to 1951 units. There was a decrease in the total extent of pastures by about 74,000 hectares, which reduced their area by about half. The table indicates a $16 \%$ decrease in the number of milk cows between 1953 and 2008, while the numbers of cattle and young animals remained constant. 
Table 2. The number of mountain pastures and the animal population in Kärnten in 1891, 1953 and 2008

\begin{tabular}{lccc}
\hline & 1891 & 1953 & 2008 \\
Milch cows & 13265 & 11273 & 1889 \\
Cattle - young animals & 57837 & 50335 & 51270 \\
Horses & 2640 & 4167 & 1635 \\
Sheep & 54781 & 49734 & 15347 \\
$\begin{array}{l}\text { Goats } \\
\text { Pigs }\end{array}$ & 10876 & 3474 & 1162 \\
$\begin{array}{l}\text { Number of meadow } \\
\text { pastures }\end{array}$ & 4517 & 1648 & $\mathrm{~S}$ \\
$\begin{array}{l}\text { Mountain pasture } \\
\text { acreage hectares }\end{array}$ & $\mathrm{S}$ & 2178 & 1951 \\
$\begin{array}{l}\text { Pasture land hectares } \\
\text { Number of employed }\end{array}$ & $\mathrm{S}$ & 154000 & 72750 \\
$\begin{array}{l}\text { at the mountain } \\
\text { pastures }\end{array}$ & 3146 & 2146 & 609 \\
& Men 1785 & Men 1232 & $\mathrm{~S}$ \\
& Women 1361 & Women 1184 & $\mathrm{~S}$ \\
\hline
\end{tabular}

$\mathrm{S}=$ information is missing

Source: Koroschitz Werner, 2009, 100 Jahre Kärntner

Almwirtschaftsverein 1909-2009. Almwirtschaft im Wandel. Kärntner

Almwirtschaftsverein, Landesmuseum Kärnten.

\subsection{Old Cheese is Sold Using New Methods}

The EU reformed its innovation policy in the early 1990s. Previously, all innovation investments had been made in research and technical development in industrial firms. These investments were expected to automatically result in innovation and economically affect the market. However, evaluations found that the research investments did not sufficiently spawn new products and market shares. The goal of the new innovation policy was to give regions assistance in helping themselves. The regional/local level was considered the best level at which to create and implement innovative measures. It was assumed that at this level it would be easiest to interact with small firms in particular. It was also considered important to take the specific conditions and requirements of the region as a starting point. No predefined recipes for business administrative success or growth-creating factors were to be imposed. Instead, the projects were to result from regional initiatives and not be imposed on regions from a higher level. Networks were to be established both within regions (i.e. between firms and the public administration) and between regions. To develop important resources for innovation purposes, such as human capital and technical development, and turn them into economic success, it was considered important to create efficient regional and national support systems. These views were widespread in the EU when Austria obtained its membership in 1995 (EU Commission 1995).

Efforts to create innovations were considered an increasingly important part of EU regional policy. A high potential for innovation in the European economy was increasingly considered an important condition for creating welfare. It was assumed to be particularly important for agrarian and industrially less-developed regions that had displayed a lower innovation capacity than that of more developed industrial regions. To foster survival, firms were to be encouraged to create competitive advantages based on producing better and different goods and services. Similarly, states were encouraged to supply national, regional, and local support systems (Grote 1997; Jonsson, Persson and Silbersky 2000; Kinkel and Wengel 1998). These views were widespread when a strategy was developed at the national level in Kärtnen to develop less developed regions. To prepare agrarian organizations and other agricultural parties for imminent EU entry, the federal state started a corporation, Kärntner Agrarmarketing AG. The aim of the corporation was to increase the value added produced by neglected agricultural producers and regions and obtain subsidies for planning projects related to food products in connection with Austria's entry into the EU. Gailtaler Käse soon became one of the large projects of the new lobbying firm, which prepared most things.

A first step was to initiate local activity groups, obtain subsidies to finance activities, and distribute the funds. According to the project leader of the application for EU certification of Gailtaler Almkäse at that time, the application was initiated by an inquiry from the state government of Kärnten about potential certification candidates among regional food products. The inquiry targeted farmers, gastronomers, and entrepreneurs in the tourism area. It was clear from federal state guidelines that only a few products could be proposed. The answers were evaluated and Gailtaler Almkäse and Gailtaler Speck (a smoked ham) were agreed on. The initiative advanced to the regional level. Local activity groups and networks involving various interested parties were created. The applications were quite extensive and complicated. The firms involved would never have been able to do this on their own, so they were assisted by a consulting firm. The costs of the applications were borne by the Austrian government and the federal state government in Kärnten, and were counter-financed by various EU funds. The application for the cheese was considered one of the best and, indeed, is still cited as an example of best practice in various contexts. These efforts were rewarded by the certification of two products from Hermagor, i.e. Gailtaler Almkäse and Gailtaler Speck, with a PDO and a PGI in 1996 and 2006, respectively. The cheese almost immediately received a PDO certificate, while certification turned out to be more difficult for the ham. These two products became the figurehead products of the region in marketing other regional food products.

\subsection{Regional economic-related effects}

Due to a desire for regional economic growth, government and corporate interest groups in Austria have shown strong interest in supporting the initiation and development of activities such as regional and local food festivals. The aim has been to create as many events as possible focusing on regionally produced food products and - to prolong the tourist season - to develop a seasonal 
culture of food festivals. The following section describes three projects connected to this aim.

\subsubsection{Gailtaler Speckfest}

According to project leader Michaela Burgstaller, it all started in 1992 with a festival to celebrate the Gailtaler Speck smoked ham produced in accordance with local traditions. The two-day speck festival has become very successful and is considered an example of best practice. To prepare for the festival, 17 agricultural firms and a slaughterhouse annually produce about ten tons of smoked speck according to strict regulations (the product obtained PGI certification upon Austria's entry into the EU in 2006) (EU 2006). At the actual festival, about five tons, or half of the yearly production, of speck are sold. In 2010, about 18,000 homemade smoked sausages were also sold. The festival has turned out to be of considerable economic importance to the development and survival of the 17 involved agricultural firms. Besides the immediate usefulness of the festival to the involved producing firms, the regional value added generated during the festival is considerable. According to municipal estimates, the regional value added amounts to about EUR 1 million, and in 2009, for example, 28,000 people attended the festival (Kleine Zeitung 2010). The festival also generates about 2000 hotel nights for tourists in Hermagor and its environs. The tourists come from the region itself and from elsewhere in Austria; they also come from nearby countries such as Italy, Slovenia, Germany, and Switzerland.

This once innovative idea for the region was itself an imitation of a previously established festival in northern Italy. The Italian city of St. Daniele traditionally holds a festival celebrating a smoked Parma-type ham (Plus Magazin 2010). According to Brugstaller, the idea was introduced by a master butcher in Hermagor who had visited St. Daniela, been impressed by the number of visitors, realized the economic importance of the festival, and 'then could not get this idea out of his head'. The Italian smoked ham festival, which lasts four days, attracts about 500,000 visitors. During the festival, visitors buy and consume about 6000 sixty-kilogram pieces of the PDOcertified ham (Prosciutto Sandaniele 2010).

The butcher became obsessed with the idea - 'if they can, we can' - and suggested to the village mayor that a similar festival be organized in Hermagor. A meeting was arranged in which representatives of agriculture, tourism, gastronomy, the chamber of agriculture, and project leader Michaela Burgstaller were present.

We also had a person who was full of ideas - an optician by profession - who participated in the meeting and who thought that the suggestion was a good idea. At an early stage, he set as the goal that the first festival was to attract a few thousand visitors to Hermagor. Everyone was laughing at him, but he did not give in and thus succeeded in persuading and involving many of us.

With the answers at hand, the project turned out to be successful and viable, and was then imitated by many others. Kärnten is today a region of culinary festivals organized around locally produced food products. In the region of Hermagor alone, which has about 19,000 inhabitants, the season starts with a polenta festival in June, followed by a speck festival, a frigg festival, a festival when the first Almkäse cheese is ready for consumption (Käseanstich), a honey festival, a bread festival, and, finally, a cheese festival in the autumn. Moreover, smaller local festivals focus on potatoes, apples, and other items. This proliferation of food festivals owes its existence to the master butcher who did not give up on an idea that he believed in.

\subsubsection{The Cheese Festival in Hermagor}

The cheese festival project was already being prepared before Austria's entry into the EU. Austria submitted an application for project funding in 1995, at the same time as its application for EU membership. This project to start cheese-related activities could have been financed by the nation, the federal state of Kärnten, and the EU. The project aim was to promote 'qualitative development of agriculture and the system of mountain pastures within the region'; in pursuing this aim, the project was to 'use highquality food products that were produced in the region'. Further goals were to improve the regional production structures of the mountain pastures and support product sales (Agrar Projekt Preis 2010).

The cheese festival has since become well established, hosting several hundred small cheese producers from Italy, Slovenia, Germany, Switzerland, and Austria that exhibit high-quality dairy and cheese products every year. Cultural events create a folkloric ambience, and traditional dancing, costumes, and handicrafts are featured at this festival visited by $12,000-15,000$ tourists every year (kaesefestival.at 2010; koemau.com 2010). In an attempt to improve the project and create further regional value added, a related project was initiated in 2001, Gailtaler Kulinarium - Gailtaler Speck- und Käse Strasse. Hemargor now had two leading products, cheese and speck, that had obtained EU certification, but there was a desire to increase the visibility of other locally produced food products as well.

The cheese festival project, which was on this occasion subsidized by national, federal state, and EU (50\%) funding, started in 2001. Local interested parties had steadily worked on four food products for some years, bread and polenta in addition to cheese and speck. The highlights of these activities are yearly festivals created around these products in the valley (Woche 2010). To create synergies and improve the region's positioning, it was decided to apply a common strategy, the main goal of which is to create new markets, inside and outside the region, for these locally produced food products. Furthermore, the common efforts should improve the region's ability to increase the value added. There were several means of obtaining these goals. A common organization was created to sell and market the products, 
building a bridge between these products, on the one hand, and local agriculture, handicrafts, trade, culture, and folklore, on the other.

Existing activities, such as the Gailtaler Käsefestival, are to be strengthened and developed into the backbone of such cooperation. Extensive infrastructure measures were introduced (e.g. producing welcome signs, signposts, individual stalls for selling goods, flyers, posters, websites, and public works), cooperation was initiated with the media, transport and tourism companies, and the credit card company Kärnten Card, and participation in official festivals was promoted (Kaerntencard.at 2010). The target area of these activities is regionally delimited to the administrative unit of Hermagor and its environs. The yearly turnover for these activities was estimated at EUR 5.8 million in 2008, half of which could be related to products such as cheese and speck and half to tourism activities related to the featured food products.

\subsubsection{Food Autumn in Kärnten (Kärntner Herbst)}

This project exemplifies success in extending the tourist season throughout the federal state by initiating seasonal food festivals in the autumn (Kaempten 2010). The project is described by those who market it as a symbiotic combination of culture, business life, and tourism. The initiative was taken by the federal state on this occasion as well. The aim was to enable all regions to display their 'cultural heritage in its most beautiful colours'.

The project seems to have been successful, and 74 municipalities participated in organizing about 120 events over two months in autumn 2009 and 2010. The participants were restaurateurs, farmers, artisans, and members of folkloric organizations such as dance groups, music groups, and shooting clubs (with a total of 80,000 members). The image conveyed was 'the colorful Kärntner soul'. The target audience was domestic tourists and tourists from nearby countries coming for the day. These ambitious plans resulted in a rich offering of events, and the number of visitors in 2009 was estimated at 220,000.

\subsection{The Advantages and Disadvantages of PDO Certification}

In reply to a question about the advantages and disadvantages related to an application for EU PDO certification, most involved agents replied that the regional economic effects were considered purely positive. The PDO and the marketing of other locally produced food products that it facilitated were interpreted as a strategy to counter the negative effects of globalization. Many people thought that the strategy had prevented the closure of existing agricultural firms, and that it had facilitated the development of other existing firms while enabling the creation of new jobs in tourism and related activities. It is not surprising that the EU, national, and federal state subsidies that had been obtained for investments, production, organizing food-related events, and marketing, were estimated. Producers were aware that the PDO had created a local monopoly that enabled agreements on cartel prices and resulting price premia. The protection of the Gailtaler Almkäse trade mark guaranteed by a PDO certificate was also important. The initially high costs of the application procedure and of quality control were mentioned as among the disadvantages.

\section{Concluding Remarks}

We have demonstrated in theory and in a case study that collective brands represent an opportunity for regions to promote regional development. Being recognized via a protected designation of origin (PDO) represents a collective brand strategy. A PDO creates a regional context for individual brands in the same product category. The interplay between competitors within the same PDO usually has strengthening effects, but may occasionally weaken some of the individual participating brands. Under a PDO, less established individual brands will benefit more from the collective brand than will already established brands, as the value of the latter spills over to the less established brands. Effective brand management can generate synergy between the brands and prevent the reliability of the collective brand from being called into question.

The initiative to create a PDO certification can be taken at a regional political level, an entrepreneurial level, or a combination of the two. The regional government will often work with local entrepreneurs to seek this certification. A successful collective brand strategy represents a source of new entrepreneurship in a geographically defined region. The regional growth so stimulated stems from the transfer of knowledge and innovation between firms in the same region, and from the increased returns of scale as the PDO can increase total production in the region. The region can gain value from by the collective brand's value, strength, and image. The Gailtaler Almkäse case illustrates how ancient methods of producing cheese in a genuine alpine landscape can constitute a starting point for developing a collective brand, as ancient regional innovations are defined, preserved, and branded by the PDO. The value of the products, in terms of price and brand value, is increased, making the collective certification-backed brand a source of renewed regional entrepreneurship.

The value of the economic spinoffs has been estimated to exceed the value of the cheese production in the Gailtaler Almkäse case. When the chalet is operating, there is often a steady stream of tourists visiting the mountain pastures to see the production. Gailtaler Almkäse exemplifies how networks and groups of firms can cooperate in entrepreneurial processes, creating collective brands for their products and producing conditions similar to those of monopsony. This interpretation, which resembles that of the collective in late Schumpeter, seems 
more suitable as a theoretical framework for this study than the perspective focusing on individuals and organizations offered by the business school approach. The examined firms cooperate with agents from authorities at the local, regional, national, and international levels to obtain the attractive certificates for their cheese and meat production.

\section{References}

[1] Aaker, D. 1991, Managing Brand Equity: Capitalizing on the Value of a Brand Name, New York: Free Press

[2] Aaker, D. 1996, Building Strong Brands, New York: Free Press

[3] Aaker D. and Joachimstaler E, 2000 Global Brand Leadership - Not Global Brands, Brand Leadership, New York: The Free Press

[4] Aaker, D. 2004, Brand Portfolio Strategy, New York: Free Press/Simon \& Schuster

[5] Agrar Projekt Preis 2010, http://www.agrarprojektpreis.at/page-83.htm downloaded: March 25, 2010.

[6] Baumol, W.J. 1993, Entrepreneurship, Management, and the Structure of Payoffs, Cambridge, Massachusetts: The MIT Press

[7] Bertolini, P. and Giovannetti E. 2006, Industrial districts and internationalization: the case of the agri-food industry in Modena, Italy, Entrepreneurship \& Regional Development, 18, (July), 279-304

[8] Birch, D.L. 1979, The Job Generation Process, MIT Program on Neighborhood and Regional Change, Cambridge: MA

[9] Borg, E. A. 1991, Problem shifts and Market Research: The Role of Networks in Business Relationships, Scandinavian Journal of Management, 7, (4), 285-295

[10] Borg, E. A. 2001, Knowledge, Information and Intellectual Property: Implications for marketing relationships, Technovation, The International Journal for Innovation, Entrepreneurship and Technology Management, 21, (8), 515-524

[11] Brockhaus, R H 1982, The psychology of the entrepreneur in Encyclopedia of Entrepreneurship

[12] Casson, M. 1982, The Entrepreneur. An Economic Theory, Oxford: Martin Robertson

[13] Casson, M. et al. (Ed) 2006, The Oxford Handbook of Entrepreneurship The Life Cycle of Entrepreneurial Ventures, Oxford: Oxford University Press

[14] Casson, M. 2010, Entrepreneurship. Theory, Networks, History. Cheltenham: Edward Elgar Publishing

[15] Chandler A. D. 1977, The Visible Hand. The Managerial Revolution in American Business, Boston Mass., Harvard University Press

[16] Chebat, Jean-Charles 1999, Introduction, special issue on strategy implementation and assessment research: Research on implementation deserves as much attention as strategy formulation, Journal of Business Research 45, 107-10

[17] Coase Ronald, 1937, "The Nature of the Firm", Economica, Vol 4. Coase Ronald, 1960, "The Problem of Social Costs", The Journal of Law and Economics. November.

[18] Commission of the European Communities, 2008, Green Paper on Agricultural Product Quality: Product standards, farming requirements and quality schemes. Brussels, Belgium: CEC

[19] Davidsson, Per 1989, Continued Entrepreneurship and Small Firm Growth, 6, 17-19

[20] Davidsson, Per 1990, Continued entrepreneurship: ability, need and opportunity as determinants of small firm growth. Umeå : Institutionen för företagsekonomi, Umeå Universitet

[21] De Chernatony, L. 1997, Integrating Brand Building using Brand Taxonomies, Journal of Product \& Brand Management, 6, (1), 56-63

[22] De Chernatony, Leslie; Harris, Fiona and Riley, Francesca 2000, Added value: Its nature, roles and sustainability, European Journal of Marketing 34: 39-56

[23] Delmar, Frédéric 1996, Entrepreneurial Behavior and Business Performance. Handelshögskolan i Stockholm.

[24] DelVecchio, D. 2000, Moving Beyond Fit: The role of brand portefolio characteristics in consumer evaluation of brand reliability, Journal of Product \& Brand Management, 9, (7), 457-471

[25] Demsetz, H. 1983, "The Neglect of the Entrepreneur", Entrepreneurship. Edited by J. Ronen, 271-280.

[26] Die Woche 2010, 100.000 Einwohner bis 2030 abwegig! 25 August 2010

[27] EU Commission, 1995, Green Paper on Innovation: Bulletin of the European Union, Supplement 5/95. Office for Official Publications of the European Community, Luxembourg.

[28] EU Commission, 2006, Decree EU No 510/2006 from the Council for the protection of geographical information and regulations of origin for agrarian products and food products "Gailtaler Speck".

[29] Feldwick P. 1996, Do We Really Need Brand Equity? The Journal of Brand Management, 4, (1), 9-28

[30] Gartner, W. B. 1988, "Who is an entrepreneur' is the wrong question", American Small Business Journal, Spring, 1-31. Gartner, W B 1990, "What are we talking about when we talk about entrepreneurship?" Journal of Business Venturing, 5 (1), 15-29

[31] Gailtaler Almprotokoll 1994, Produktions- und Qualitätsrichtlinien und Kontrollsystem für den "Gailtaler Almkäse". Unpublished manuscript. Verein der Gailtaler Almgesellschaften

[32] Global Entrepreneurship Monitor 2008. http://www3.babson.edu/ 10/10/08

[33] Globaliseringsrådets olika http://www.sweden.gov.se/sb/d/8616 rapporter: 
[34] Graetz, F. 2000, Strategic Change Leadership, Management Decision, 38, (8) 550-564

[35] Granovetter, M. 1973, The strength of weak ties, American Journal of Sociology, 78, 1360-80

[36] Gratzer K. and Rykönen P. 2012, Geografisk ursprungsbetekningar, En prelimenär reflektion, Södertörns högskola, Working Paper 2012:2

[37] Gratzer K., Rykönen P., Wramner P., 2011, "Landsbygdsutveckling, entreprenörer och varumärkesstrategier - en pilotstudie om gårdsmejerier i Sverige", in: Lönnborg, M and Rytkönen, P. 2011, Business History in Sweden. Gidlund,

[38] Gratzer, K. 2011, "Regional utveckling genon SUB certifiering - Fallet Gailtaler Almkäse" Ymer. Årsbok. Svenska Sällskapet för Antropologi och Geografi.

[39] Grote J. R. 1997, Regionale Vernetzung: Interorganisatorische Strukturdifferenzen regionaler Politikgestaltung, (Arbeitspapiere Arbeitsbereich III/23). Mannheimer Zentrum für Europäische Sozialforschung, Mannheim

[40] Hébert, R. F. and Link A. N. 1982 The Entrepreneur. Mainstream Views and Radical Critiques

[41] Hakansson H. and Johanson, J, 1994, A model of industrial networks, in Axelsson B. and Easton G. (Eds.) Industrial networks: A new view of reality, London: Routledge

[42] Henreksson, Magnus and Stenkula, Mikael 2007, Entreprenörskap, SNS, Stockholm

[43] Higgins, R and Johnston A. 2010 Knowledge Flow and Inter-firm Networks: The influence of network resources, spatial proximity and firm size, Entrepreneurship \& Regional Development, 22, (5), 457-428

[44] Higgins, R and Williams N. 2011, Entrepreneurship and Regional Competitiveness: The role and progression of policy, Entrepreneurship \& Regional Development, 23, (910), $907-932$

[45] Hisrich, Robert D et al 2008, Entrepreneurship, McGraw Hill, 168-195

[46] Hoselitz, B F, 1951 The Early History of Entrepreneurial Theory in Explorations in Entrepreneurial History, 3, (4), 193-222.

[47] Ireland, R.D.; Covin, J.G. and Kuratko D.F. 2009, Conceptualizing Corporate Entrepreneurship Strategy; Entrepreneurship Theory \& Practice, January, 19-46

[48] Ireland Norman J, 1987, Product Differentiation and Nonepricecompetition, Oxford and New York: Basil and Blackwell.

[49] Jaworski, Bernard and Kohli, Ajay 1993, Market orientation: Antecedents and consequences, Journal of Marketing, 57, 53-70

[50] Johannisson, Bengt 2009, "Varför är entreprenörer så obegripliga och ändå vad de gör så begripliga?”, in: Företagsekonomins frågor, red. Brunsson Nils, Stocklholm: Nordstedts

[51] Johannisson, B. and Rezpasillas, M. 2002, The institutional embeddedness of local inter-networks: a leverage for business creation, Entrepreneurship \& Regional Development, 14, 297-315

[52] Jonsson O.; Persson H. and Silbersky U., 2000, Innovativitet och regioner. Företag, processer och politik. Swedish Institute for Regional Research. Rapport 2000: 121

[53] Kärntner Landesregierung 1970, Das ist Kärnten

[54] Kay, Mark J. 2006, Strong Brands and Corporate Brands, European Journal of Marketing, 40, (7/8), 742-760

[55] Kaempten 2010, http://www.kaernten.at/de.aspx/channel/herbst/season/herbs $\mathrm{t}$

http://www.kaernten.at/de.aspx/Articles/List/18.08.2009/to/ 18.08.2010/Essen-Trinken/filter/Essen-Trinken

[56] Keller, K.L.; T. Apéria and M. Georgson 2008, Strategic Brand Management; Essex, UK: Pearson

[57] Keller, K.L and Lehmann D. R. 2003, How Do Brands Create Value? Marketing Management, 12, (3), 26-31

[58] Kinkel S. and Wengel J. 1998, Produktion zwischen Globalisierung und regionaler Vernetzung, in Mitteilungen aus der Produktionsinnovationserhebung, Fraunhofer Institut. Systemtechnik und Innovationsforschung, No 10, April 1998

[59] Kleine Zeitung 2010 http://www.kleinezeitung.at/kaernten/hermagor /hermagor_pressegger_see http://www.kleinezeitung.at/kaernten/hermagor /hermagor_pressegger_see/1995235/index.do

[60] Kilby, P. 1971, Hunting the Heffalump, in Kilby, P. (ed), Entrepreneurship and Economic Development, New York: Free Press;

[61] Kirzner, I. 1973, Competition and Entrepreneurship, Chicago: University Press

[62] Kleine Zeitung http://www.kleinezeitung.at/kaernten/hermagor/ hermagor_pressegger see/1998983/index.do http://www.kleinezeitung.at/kaernten/hermagor /hermagor_pressegger_see/1995235/index.do

[63] Knight, F. H. 1921, Risk, uncertainty and profit, Boston: Houghton Mifflin

[64] Knight, G. 2000, Entrepreneurship and Marketing Strategy: The SME Under Globalization, Journal of International Marketing, 8, (2), 12-32

[65] Korsgaard, S. 2011, Entrepreneurship as Translation: Understanding entrepreneurial opportunities through actornetwork theory, Entrepreneurship \& Regional Development, $23,(7-8), 661-680$

[66] Lamprinoupoulou C. and Tregear, A. 2006, Agrifood SMEs in Greece: the role of collective action, British Food Journal, $108,(8), 663-676$

[67] Landström, Hans 2005, Pioneers in Entrepreneurship and Small Business Research, ISEN, Springer

[68] Landström, H. and Lohrke, F., 2010, Historical Foundations of Entrepreneurship Research. Cheltenham: Edward Elgar Publishing 
[69] Laforet, S. and Saunders J. 1999, Managing Brand Portefolios: Why leaders do what they do, Journal of Advertising Research, 39, (1), 51-66

[70] Lebemnsmitteln Kaernten 2010, http://www.lebensmittelkaernten.at/ download: December 12010.

[71] Low, George S. and Ronald A. Fullerton 1994, Brands, Brand Management, and the Brand Manager System: A Critical-Historical Evaluation, Journal of Marketing Research, 31, (May), 173-190

[72] Malecki E. J. 1997, Technology and Economic Development. The development of local, regional and national competitiveness, Harlow: Addison Wesley and Longman

[73] Marian, V and Dimitratos 2004, Emerging Paradigms in International Entrepreneurship. Edwar Elgar Celtenham, UK

[74] Mintzberg H. 1987, Five P's for Strategy, California Management Review, 30, 11-24

[75] Morris, A, and Paul, G. 1987 The Relationship Between Entrepreneurship and Marketing in Established Firms, Journal of Business Venturing, 2, (3), 247-259

[76] Nikolaou, E.I.; Ierpetritis, D. and Tsagarakis, K.P. 2011, An evaluation of the prospects of green entrepreneurship development using a SWOT analysis, International Journal of Sustainable Developm,ent \& World Ecology, 18, (1), 116

[77] Noble, Charles 1999, The eclectic roots of strategy implementation research, Journal of Business Research 45, $119-35$

[78] OECD Innovation Srategy 2009, Innovation in Firms. A microeconomic Perspective. OECD publishing

[79] Otuteye, E. and Sharma B. 2004, A transaction cost and transformational generative model of aggregate entrepreneurship, The Journal of Entrepreneurship, 13, (2), 153-165

[80] Parker. Simon C. 2007 International Handbook Series on Innovation, Ed by K.R. Polenske Cambridge: Cambridge University Press.

[81] Plus Magazin 2010, http://www.55plusmagazin.net/php/ aria_di_festa schinkenfest in san_daniele_zu_ehren_des_schinkens, 16971,7473.html

[82] Polenske K.R. Ed 2007, The Economic Geography of Innovation, Cambridge: Cambridge University Press

[83] Porter, M.E., 2003, The Economic Performance of Regions, Regional Studies, 37, (6), 545-546.

[84] Porter, M.E., 1998, Konkurrensstrategi. Tekniker för analyser av branscher och konkurrenter, Göteborg: ISL förlag.

[85] Prosciutto Sandaniele 2010 , http://www.prosciuttosandaniele.it/en/consorzio_strumento. html, Download March 29, 2010.

[86] Redlich, Fritz 1964, Der Unternehmer. Schumpeter, J A 1952, Geschichte der ökonomischen Analyse. Band II, 1965.
[87] Regiomarket

http://www.regiomarket.org/index.php?id=40

2010

[88] Reynolds Paul D, Bygrave William D, Autio Errko and Hay Michael, 2002, Global Entrepreneurship Monitor Executive Report, Babson College and London Business School.

[89] Rytkönen, P and Gratzer, K. 2010, "When do trademarks create new markets?: Entrepreneurship, brands and growth - experiences from small scale cheese production in Austria, Spain and Sweden" i Building sustainable rural futures: the added value of systems approaches in times of change and uncertainty; 9th European IFSA Symposium Vienna; Proceedings.

[90] Sandahl, J-U., 2003, Jakten på Entreprenören, Lund: Almquist \& Wiksell International;

[91] Say, J.B. 1816, Catechism of Political Economy, London: Sherwood, Neely and Jones

[92] Schumpeter, J.A. 1911, Theorie der wirtschaftlichen Entwicklung. Leipzig: Dunker \& Humblot

[93] Schumpeter J.A. 1947a The Creative Response in Economic History, Journal of Economic History, 7, 149159

[94] Schumpeter J.A. 1947b, Theoretical Problems of Economic Growth

[95] Schumpeter J.A. 1949, Economic Theory and Entrepreneurial History.

[96] Schumpeter J A 1994 "Ekonomisk teori och entreprenörskapets historia" i: Schumpeter. Om skapande förstörelse och entreprenörskap i urval av R. Swedberg.

[97] Sexton, D.L et al 1986 The Art and Science of Entrepreneurship, Edited by Sexton, D. L. \& Smilor R. W.

[98] Shane, S. 2003, A General Theory of Entrepreneurship, The Individual-Opportunity Nexus, Cheltenham: Edward Elgar Publishing;

[99] Shepherd, William G. 1996, The Economics of Industrial Organization. New York, Prentice Hall.

[100] Storey, David, 1994, Understanding the Small Business Sector, London: Routledge

[101] Teresa da Silva, Lopes and Mark Casson 2007, Entrepreneurship, Brands and the Development of Global Business. Working Papers, Centre for globalization Research, No.2 (September)

[102] Vakoufaris, H. 2010, The Impact of Ladotyri Mytilinis PDO cheese on the Rural Development of Lesvos Island, Greece, Local Environment, 15, (1), 27-41

[103] Van Gelder, S. 2004, Global Brand Strategy, Journal of Brand Management, 12, (1), 39-48

[104] Varadarajan, R.; DeFanti, M.P.; Busch, P.S. 2006, Brand Portfolio, Corporate Image, and Reputation: Managing brand deletions, Journal of the Academy of Marketing Science, 34,2, 195-205

[105] Welsch, H 1992, International Entrepreneurship and Small Business Bibliography 
[106] Werker, C and Athreye S. 2004, Marshall's Disciples: Knowledge and innovation driving regional economic development and growth, Journal of Evolutionary Economics, 14, 505-523

[107] Woche 2010; For the polenta festival, see http://www.woche.at/noetsch-im-gailtal/kultur/18polentafest-noetsch-d16104.html, for the bread festival see http://www.woche.at /lesachtal/ kultur/lesachtaler-dorf-undbrotfest-d12372.html.
[108] Von Schwarzfurtner R. 2009, Kärnten schrumpft, weil Zuwanderer ausbleiben and"Österreich wird alt und grau in Kärntner Tageszeitung, October 9. 2009

[109] Wood, L. 2000, Brands and Brand Equity: Definitions and Management, Management Decisions, 38, (9), 662-669

[110] Wright, R. W. and Dana L.-P. 2003 Changing Paradigms of International Entrepreneurship Strategy, Journal of International Entrepreneurship, 